\title{
Bujdos ÁGnes*
}

\section{Vízszemléletü kormányzás - vízpolitika - vízjog}

2018 nyarán jelent meg Szilágyi János Ede, a Miskolci Egyetem Állam- és Jogtudományi Kar Agrár- és Munkajogi Tanszéke egyetemi docensének monográfiája, Vízszemléletü kormányzás - vízpolitika - vízjog címmel. A 313 oldal terjedelmü könyvet a Miskolci Egyetemi Kiadó gondozta, alapja pedig egy, a Bolyai János Kutatási Ösztöndíj támogatásával végzett kutatás.

\section{A téma aktualitása}

A vízre mint létfontosságú, mással nem helyettesíthető és korlátozottan rendelkezésre álló természeti erőforrásra vonatkozó jogi szabályozás elemzésének fontosságára már a szerző 2013-ban megjelent, Vízjog (Aktuális kihívások a vizek jogi szabályozásában) címü kötetének a bemutatása során felhívtam a figyelmet. ${ }^{1}$ Ezért most, az új kötet apropóján célszerü inkább a két kötet közötti kapcsolatra, illetve az új kutatás aktualitására és jelentőségére fókuszálnom. Először is fontos kiemelni, hogy a Vízjog c. kötet első fejezete, a Vízjogi alapvetések középpontjában a vízkörforgás és a vízhasználatok, valamint a vizekhez kapcsolódó nemzetközi, európai uniós és magyar kihívások bemutatása állt. Az ott tett megállapításoknak a megismétlésére magától értetődően a jelen kötetben nem került sor, azonban ezen összefüggések ismeretének hiányában a szerző elemzései és az új kutatás eredményei nem értelmezhetőek. Egy másik említésre méltó kapocs a két mű között a jogi megközelítés alkalmazása. A 2013-ban megjelent kötet - a címével összhangban - a vízhez kapcsolódó kérdéseknek kizárólag a jogi vetületére koncentrált, és magában foglalta a vizek tulajdonlására és használatára vonatkozó szabályokat; a vizek védelmének nemzetközi, EU-s és hazai szabályozását; a víz mint áru és szolgáltatás elemzését (különös tekintettel a víziközmű-szolgáltatásokra); továbbá a víz egyéb jogi koncepcióit. A vízjogi rész a jelen kötet negyedik és ötödik fejezetében kap helyet. Noha nyilvánvalóan (és szükségszerüen) van átfedés a két munka között, ugyanakkor egyes részek vonatkozásában a korábbinál részletesebb elemzéssel találkozhatunk, míg a 2013-as kötetben hangsúlyos szerepet betöltő víziközmú-szolgáltatásokra vonatkozó szabályozás bemutatására nem kerül ismételten

* Dr. Bujdos Ágnes tudományos munkatárs, Debreceni Egyetem Állam- és Jogtudományi Kar Agrárjogi, Környezetjogi és Munkajogi Tanszék, Debrecen; bujdos.agnes@law.unideb.hu. A recenzió alapjául szolgáló kutatást az Emberi Erőforrások Minisztériuma által meghirdetett Felsőoktatási Intézményi Kiválósági Program támogatta, a Debreceni Egyetem 4. tématerületi programja keretében.

Bujdos Ágnes: Vízjog (Aktuális kihívások a vizek jogi szabályozásában). Pro Futuro, 2014/1, 163. 
sor. Mindemellett az új kötet megközelítése már a jogtudomány keretein túlra mutat, amennyiben a címnek megfelelően a vízszemléletủ kormányzással és a vízpolitikai szemléletmóddal egészül ki. Ennek a szemléletmódosításnak a hátterében egyrészt a 2017-ben elfogadott Nemzeti Vízstratégia áll (amely szükségszerüen interdiszciplináris, és a jogi aspektusnál egy jóval komplexebb megközelítésmód jellemzi). Másrészt a szerzőnek az állam- és jogtudomány képviselőjeként volt lehetősége részt venni a Nemzeti Víztudományi Kutatási Program előkészítésében az MTA Víztudományi Koordinációs Csoport tagjaként, így közvetlenül is tapasztalhatta a vízre vonatkozó szabályozás komplexitását és a különböző tudományterületek együttműködésének szükségességét. Következésképpen elmondható, hogy a Vízszemléletú kormányzás - vízpolitika - vízjog címü kötet a korábbi könyv folytatásának tekinthető, ugyanakkor a kutatás mélyült és új területekkel egészült ki.

\section{Sajátos szerkezet}

A Bevezetőt követően az Összegző megállapitások következnek, melyeket öt érdemi fejezet követ, a könyv legvégén pedig az irodalomjegyzék található. Ezzel kapcsolatban érdemes megjegyezni, hogy a szerző már a Vízjog címü kötetében is sajátos szerkezeti megoldást választott. Akkor a bevezetést és az öt érdemi fejezetet követte az összegzés. Ez utóbbinak az érdekességét az adta, hogy először a vízre vonatkozó általános következtetéseket vont le a szerző, és csak ezt követően kerül sor az egyes problémákra vonatkozó konklúziók megfogalmazására. Ráadásul ez utóbbiak nem minden esetben igazodtak a fejezetekhez. Visszatérve a jelen könyv felépítésére, a kötet egyik sajátosságának tekinthető, hogy közvetlenül a bevezetés után találhatóak az összegző gondolatok. Ez a megoldás önmagában véve meglepő lehet, hiszen lehetővé teszi az olvasó számára, hogy a problémafelvetést követően, rögtön választ kapjon a kutatás legfontosabb kérdéseire, vagyis a szerző elemzései már az eredmények birtokában olvashatók. Azonban a kötet egyik legdominánsabb kutatási módszere a fogalomelemző módszer, melynek köszönhetően sok fogalom, koncepció elemzésére kerül sor, ráadásul több (nemzetközi, EU-s, nemzeti) szinten. Mivel ennek a tárgyalási módszernek az a sajátossága, hogy az egyes (nem feltétlenül egymást követö) gondolatmenetek szoros kapcsolatban állnak egymással (olykor a mü több részével is), ezért az ilyen kutatások eredményeit absztrahálni mindig nagy kihívást jelent. Így ez a megoldás elsősorban azokat az olvasókat segíti a kutatás eredményeinek a megértésében, akik alapos előképzettséggel rendelkeznek a víztudományok területén.

Rátérve a könyv egyes témaköreinek bemutatására, a Vízszemléletü kormányzás címet viselő első fejezet, a vízszemléletű kormányzás magyar nyelvű elnevezésének kialakulását, valamint a kormányzás és a jó kormányzás mibenlétét járja körül, majd a vízszemléletủ kormányzás és a vízgazdálkodás viszonyát tisztázza. Ezt követően a vízszemléletủ kormányzás nemzetközi koncepciójának elemzésére kerül sor, különös tekintettel a Víz Világjelentésekre. A fejezetet a vízszemléletủ kormányzás hazai koncepciójának bemutatása zárja. 
A második fejezet, Az integrált, adaptív és tájszemléletü vízgazdálkodás, a vízgazdálkodási koncepciónak a változását ismerteti a nemzetközi dokumentumokon keresztül, majd ezt követően a fejezetcímben szereplő három speciális vízgazdálkodási koncepció bemutatására kerül sor.

A harmadik fejezet $A$ víztudomány(ok) és a vízszemléletü tudomány címet viseli, és a témát a nemzetközi kitekintést követően, a víztudomány magyarországi értelmezésére (elsősorban a Nemzeti Vízstratégián keresztül) koncentrálva dolgozza fel.

A negyedik, $A$ vízpolitika címet viselő fejezet, a nemzetközi vízpolitikai célok vizsgálatával kezdődik, a vízhez kapcsolódó fenntartható fejlesztési célok előzményei, és maguk a célok tükrében. Ezt követőn kerül sor az Európai Unió vízpolitikájának (különös tekintettel a Víz Keretirányelvre) és a magyar vízpolitikának az elemzésére.

Az ötödik fejezet tárgyát $A$ vízjog és a vízszabályozás koncepciói képezik. A fejezet első része a vízjog elnevezésével és tartalmával foglalkozik, nemzetközi, európai uniós és nemzeti szinten. A második rész középpontjában a víz egyes szabályozási koncepciói állnak: a víz mint önálló jogalany, rendelkezési hatalom tárgya, környezeti elem, áru és szolgáltatás, illetve káresemény. Továbbá a vízhez való jog és a vízgyűjtő mint intézményszervezési alap bemutatása.

\section{Tartalmi áttekintés}

Szilágyi János Ede a kutatási eredményeinek publikálásával egyrészt a „közös tudományos kommunikációs keret és nyelvezet kiépítéséhez" kíván hozzájárulni. Másrészt a szerző célja a „jogtudomány előrébb vitele a napjainkban víztudománynak nevezett tudományos közegben". Ezeknek a céloknak az eléréséhez a kötet címében szereplő három témát, nevezetesen a vízszemléletủ kormányzást, a vízpolitikát és vízjogot, öt érdemi fejezetben tárgyalja. Első ránézésre rögtön feltűnik, hogy a három téma feldolgozása nem azonos arányban jelenik meg, továbbá, hogy az egyes fejezetek hosszában is jelentős eltérés található. Ennek ellenére egyet lehet érteni a szerző által alkalmazott megoldással, amely szoros összefüggésben áll a kutatás módszertanával. A három terület közötti szoros kapcsolat továbbá abban is megnyilvánul, hogy folyamatosan találkozhatunk a könyvben a korábbi vagy éppen a későbbi részek elemzéseire való hivatkozással.

A szerző elsősorban interdiszciplinárisnak tekinti a saját kutatását. Ez a megállapítás helytálló a könyv egészére (pl. vízjog és vízpolitika), és sok esetben az egyes (al)fejezetekre is (pl. a vízszemléletú kormányzás horizontális kérdései). Továbbá, ahogyan az 1. pontban már utaltam rá, a vízhez kapcsolódó kérdések értelmezése csak a természettudományos összefüggések ismeretében lehetséges, így minden, a vízhez kapcsolódó jogi és társadalomtudományi kutatás szükségszerủen interdiszciplináris. Véleményem szerint azonban a kutatás szempontjából nem kevésbé fontos a fogalomelemző módszer használata, amelynek eredményeképpen a szerző egyfelöl több szakkifejezés jelentését próbálja tisztázni, másfelől rávilágít a fogalomhasználathoz kapcsolódó, egyes bizonytalanságokra. Ezek az elemzések tekinthetők a kutatás talán legfontosabb eredményeinek. A fent említett két kutatási módszer mellett több alkalommal megjelenik a történeti módszer használata is (pl. Nemzeti 
Víztudományi Kutatási Program elindítása és a Víztudományi Kutató Intézet létrehozása, a Víz Világjelentések bemutatása, a magyar vízjog fejlődése). Végezetül a módszertani kérdésekhez kapcsolódóan a szerző által választott vizsgálati szintekröl kell még néhány szót ejtenem. Már a Vízjog című kötetnél megfigyelhető volt egy-egy kérdés vagy probléma vonatkozásában, amennyiben a szerző indokoltnak látta, a nemzetközi, az EU-s és a nemzeti szint bemutatása. Ez a szemléletmód szerencsére az új kötetet is jellemzi, sőt ezeken felül többször még a helyi szint jelentőségének említésére is sor kerül. Ennek a megközelítésnek a jelentőségét az adja, hogy a Föld vizei egy hidrológiai egységet alkotnak, s erre minden tudományterületnek, illetve minden szabályozási szintnek tekintettel kell lennie. Ennek eredményeképpen a szerző nagy hangsúlyt fektet az egyes szabályozási szintek egymáshoz kapcsolódására, és arra, hogy hogyan hatnak egymásra (pl. hogy az EU vízstratégiája az integrált vízgazdálkodás koncepciójának a meghatározását az ENSZ Rio+20 Nyilatkozatra hivatkozva adottnak veszi). Az egyes célok, koncepciók vagy problémák hatása azonban nemcsak felülröl lefelé érvényesülhet (pl. a klímaváltozás mint univerzális probléma EU-s, illetve nemzeti szinten való megjelenése), hanem alulról felfelé is (pl. egy helyi szinten azonosított probléma megjelenése elöbb a nemzeti, majd az EU-s szinten).

A feldogozott források vonatkozásában ki kell emelni, hogy a szerző nagyszámú elsődleges forrásra támaszkodott a munkája során. A vízhez kapcsolódó szabályozás sajátosságaira való tekintettel az is pozitívum, hogy a csekély számú kötelező erővel rendelkező dokumentum mellett hangsúlyos szerepet kaptak a kötelező erővel nem rendelkező, de a vízjog és a vízpolitika terén kiemelkedő szerepet játszó dokumentumok, mint pl. a Víz Világjelentés vagy a fenntartható fejlödési célok. Ugyanez a megállapítás alkalmazható az egyes szervezetek tevékenységére is, így az ENSZ és az Európai Unió mellett említésre került többek között a Nemzetközi Vízkészletek Egyesület, illetve a Víz Világfórum. Ennek köszönhetően átfogó képet kapunk a vízminőségi és -mennyiségi problémákról, kihívásokról, továbbá a vízhez kapcsolódó káreseményekről. A felhasznált források nagy száma és alapos elemzése is jelzi, hogy a szerző komoly ürt töltött be új könyvével. Mindemellett a most ismertetett könyv - a szerző eddigi munkássága s a vízjogi témakör hatalmas terjedelme tükrében - vélhetőleg csupán újabb állomása, és nem lezárása egy kutatásnak. A folytatás során érdemes kiterjeszteni a figyelmet a vízjoggal és vízszemléletủ kormányzással foglalkozó további kutatások eredményeire, amelyek pl. az Utrecht Centre for Water, Oceans and Sustainability Law ${ }^{2}$ és a University of Dundee Centre for Water Law, Policy and Science ${ }^{3}$ keretében zajlanak. E kutatómühelyeknek a publikációit is felhasználva egyes témák még tovább árnyalhatók, és esetleg új kutatási irányokhoz is meríthetők inspirációk.

2 Ezen intézményben többek közt a klímaváltozáshoz való adaptáció, a palagáz-kitermelés és az árvízi menedzsment vízjogi és vízkormányzási kérdéseivel foglalkoznak, https://www.uu.nl/en/node/30481/waterlaw-and-governance (2018. 07. 30.).

3 Itt kulcskérdésként jelenik meg a vízkormányzás hatékonysága és igazságossága, https://www.dundee.ac.uk/ water/ (2018. 07. 30.). 


\section{A kötet felhasználhatósága}

Szilágyi János Ede könyve nemcsak hiánypótló a magyar szakirodalomban, hanem a Nemzeti Vízstratégia 2017-es elfogadásának köszönhetően aktualitásához sem férhet kétség. Interdiszciplináris szemléletének köszönhetően, mely elsősorban a vízjogi és vízpolitikai megközelítésben tükröződik, egyszerre tarthat számot több tudományterület, illetve a jogalkotás és a jogalkalmazás érdeklődésére is. 